SHS Web of Conferences 23, 03004 (2016)

DOI: $10.1051 /$ shsconf/ 20162303004

(C) Owned by the authors, published by EDP Sciences, 2016

\title{
THE IMPROVEMENT OF THE VENTILATION SYSTEM IN THE EXISTING TERRACED HOUSES IN MALAYSIA
}

\author{
Yasser Arab ${ }^{1}$ and Ahmad Sanusi Hassan ${ }^{2}$ \\ School of Housing Building and Planning, Universiti Sains Malaysia \\ 11800 , Penang, Malaysia \\ 1: yasserarab2005@yahoo.com, 2: sanusi@usm.my
}

\begin{abstract}
This study aims to find a sustainable solution in order to reduce the indoor temperature in hot and humid climate such as Malaysia. The focus of this study is to create a new device (Air Tube) which is considered to be a remedial device for the indoor spaces, and can be installed for the existed houses. The method of this study is to design the Air Tube device and install is in the rooms of second floor in semi-detached and terrace house in order to reduce the temperature few degrees. The study will depend on taking manual measurements in the site and making simulation using computer software Ecotect on $14^{\text {th }}$ of February (which considered to be the hottest day in the year) and trying to find the best solution to reduce the temperature in such hot and humid weather, the case study is a semi-detach house with postmodern architectural style, which is located in Sungai Petani, Kedah, Malaysia. The research finds that AirTubeis a good solution for the existed houses to decrease the temperature and reach the thermal comfortable atmosphere.
\end{abstract}

Key Words: AirTube, Ecotect, semi-Detached Houses

\section{INTRODUCTION}

One of the most important issues which are facing architects nowadays is to reduce the energy consumption in building. The residency buildings are tend to be a very wide aspect of buildings where many studies and researches have taken place in term of daylighting, shading, energy generating and ventilation system seeking clean and sustainable solutions for energy consumption (Ihm, et al. 2009, Bodart and Herde 2002, J. Hirunlabh, et al. 1999), all previous studies focused on creating new strategies and techniques in order to have alternative energy resources for the new buildings whereas this study focuses on houses which already existed. The study aims to create a new device which is considered to be a remedial device (Air Tube) for the indoor spaces and can be installed for the existed terrace and semi-detached houses in Malaysia. Air Tube works on improving the natural ventilation system in order to reduce the temperature few degrees to reach the thermal comfort average, and as a result reducing using artificial air conditioning and electricity. 


\section{PROBLEM STATEMENT}

In a country like Malaysia which is tropical and considers being tropical country, the problem of hot and humid is one of the most important issues that must be under control especially in housing building. Modern Houses are not designed to have good cross natural air ventilation. Their design instead is to comply with air conditional usage. It is the aim of this study to promote the use of 'air tube' as a remedial device o the indoor houses by inducing air ventilation generated due natural stack effect system as an alternative to cross natural air ventilation system. Some studies tried to come out with solution in many parts in the word such as using the wind catcher or wind chimney and the Islamic and traditional architecture in some of the Arab countries like Syria, Iraq and Egypt and Iran (El-Shorbagy, 2010, El-Shorbagy, 2010 and Montazeri, Montazeri, Azizian, \& Mostafavi, 2010).

And some other studies in the tropical countries like Malaysia and Thailand which have different circumstances in terms of the wind, temperature and humid, these studies depended on the stack effect. But all those studies where trying to come out with a good solution for natural ventilation systems for the new buildings such as a Metallic Solar Wall (Hirunlabh, Kongduang, Namprakai, \& Khedari, 1999) and a Solar Chimney (BANSAL, MATHUR, \& BHANDARI*, 1993).

\section{CASE STUDY}

The case study is a semi-detached house located in Sungai Petani, Kedah, Malaysia with coordinates: $5^{\circ} 39^{\prime} \mathrm{N} 100^{\circ} 30^{\prime} \mathrm{E}$. Sungai Petani is the largest town in the state of Kedah (statistics 2010, Ju and Omar 2010), which was found in 1915 by Sir George Maxwell the first British advisor to Kedah (Wikipedia 2013). The case study is a semi-detach house from to stories was built during the 2000 s with post-modern architectural style (Figure $1 \& 2$ )

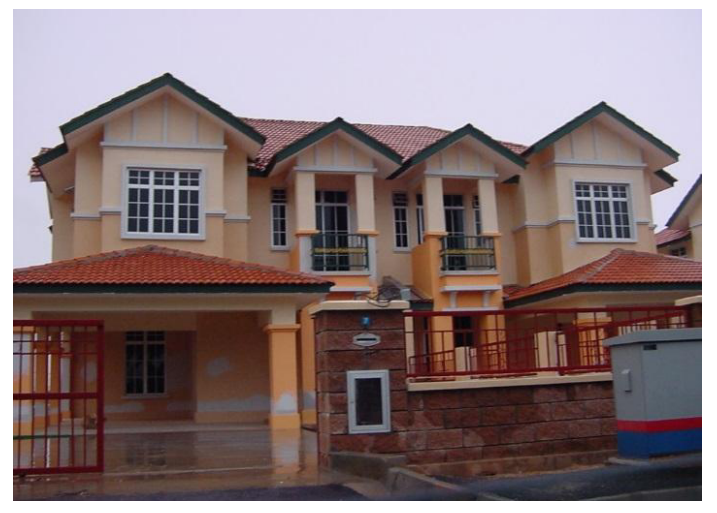




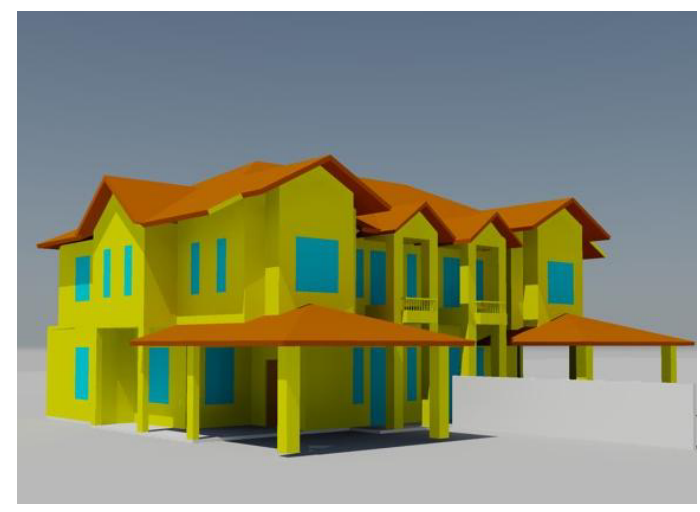

Figure 1. Case study, Semi-detach house (photo and perspective)
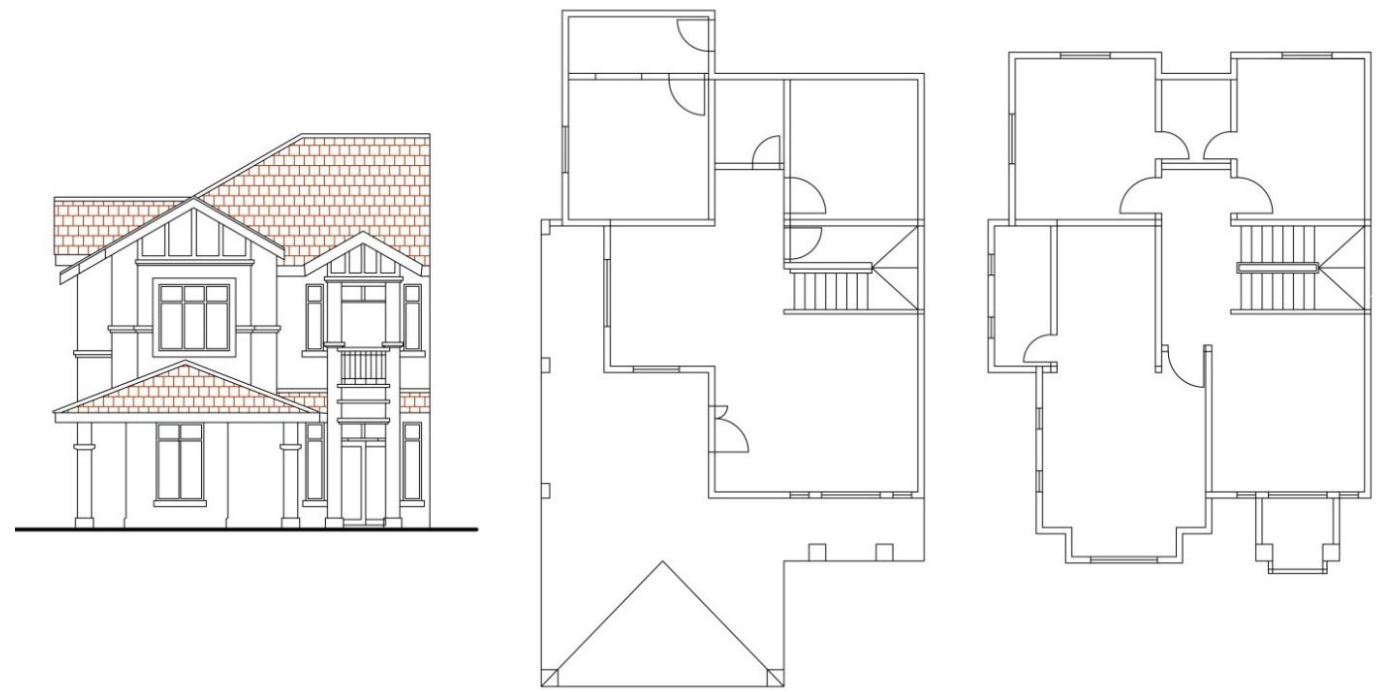

Figure 2. Case study (Left: Elevation, Middle: Ground floor plan and Right: First floor plan)

\section{METHODOLOGY}

Having a cool weather and good ventilation system using the natural wind crossing the house considers as an excellent building passive design, which match with comfortable factors for the human being requirements. The scope of this study is to simulate the indoor temperature of the case study by using computer software from Autodesk known as Ecotect, and to analyze the results and compare it with the thermal comfort zone averages in hot and humid climate, the simulations take a place on $14^{\text {th }}$ of February the hottest day in the year (Crawleya, et al. 2008, Attia, et al. 2009). The simulation was conducted after a three dimensions drawing of the case study was created using AutoCAD 2013 computer software. The three dimension geometry was imported into Ecotect software after saving it in DXF format and then the simulation has done and got the results. The software will do series of thermal simulation to get the temperature in selected rooms in the upper story (Figure 3), the 
simulation will be done before and after installing the Airtube in order to do the comparative study.

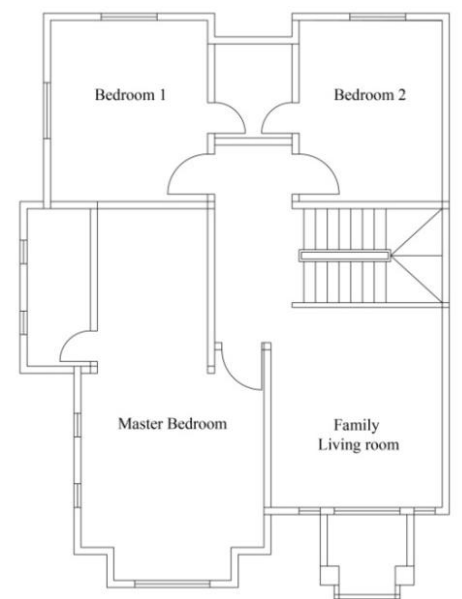

Figure 3. Thermal analysis selected areas.

\section{MEASUREMENT SCALE}

The scale of the measurement can be identified by the temperature level, humidity and wind speed, which can show the performance of cross air ventilation and stack effect. The measurable scale for temperature is in Celsius, humidity in percentage and wind speed in meter per second. The device used to record the scale of measurements is anemometer. The measurable scale of the temperature refers to The Canadian index (2009), called Humidex. This index categories human comfort level which is to 'reflect perceived temperature' using combination of temperature and humidity. There is so far no study conducted to give a specific measurable scale of the temperature in the tropical region. The measurable scale also refers to the study of Abdul Rahman. The reason is that perception by the people who live in tropical regions are different from those in temperate and cold regions (Lipinga and Hien 2007, Singha, Mahapatrab and Atreya 2010). Abdul Rahman (1995) in his study found that the most comfortable indoor temperature in Malaysia (tropical region) ranges from $25.5 \mathrm{o} \mathrm{C}$ to $280 \mathrm{C}$ compared to the general recommendation by World Health Organization (Organization 1990), from $18 \mathrm{oC}$ to $28 \mathrm{oC}$. The reason is hot and humid temperature throughout a year gives an impact to the people's perception to the thermal comfort at higher temperature in contrast to those in temperate region. Scale No. 2 (Table 1) is considered as the best level of performance of the temperature factor. The measurable scale is as follows:

Table 1. The scale of measurement for temperature

\begin{tabular}{|l|l|l|}
\hline Scale & Description & Celsius \\
\hline 0 & Cold & Less than 16 \\
\hline 1 & Temperate & $16-25.5$ \\
\hline
\end{tabular}




\begin{tabular}{|l|l|l|}
2 & Comfort & $25.5-28$ \\
\hline 3 & Warm & $28-32$ \\
\hline 4 & Hot & $32-40$ \\
\hline 5 & Extremely Hot & Above 40 \\
\hline
\end{tabular}
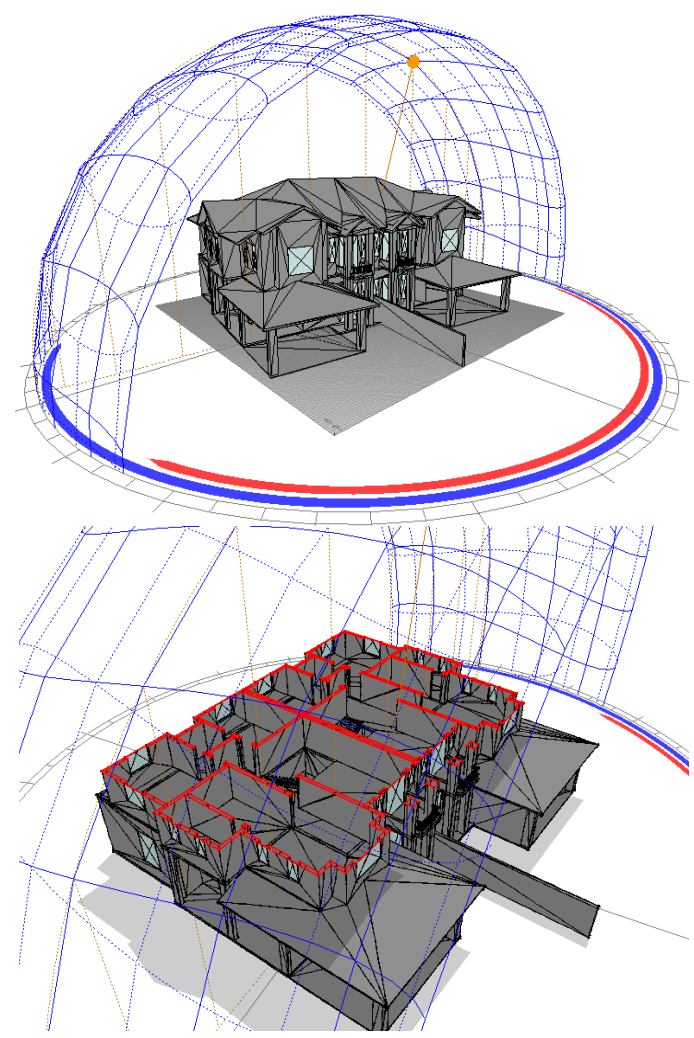

Figure 4. Sun path during the year and day (left) semi-detached house perspective, (right) perspective section.

\section{RESULTS OF ANALYSIS}

After getting the simulation's results, a comparative study creates in order to compare between the temperature before and after installing one AirTube in the center of each selected room with dimensions $(60 \mathrm{~cm} * 60 \mathrm{~cm})$, Table 2 and Figure 5 show the temperature of the selected rooms before and after from 8:00 am until 7:00 pm on $14^{\text {th }}$ of February, the results show that AirTube managed to reduce to temperature at all of the simulations hours in all of selected rooms. The best performance was recorded in the Family Living area at the evening 
hours from 3:00 pm until 7:00 pm, as the device managed to reduce the temperature and make 6 degrees difference in the room temperature before and after installing the AirTube.

At the Master Bedroom the AirTube device starts with better performance at the early morning hours of simulations from 8:00 to 10:00 am with reducing the temperature about 4degrees, and then it completes rest of the hours with reducing the temperature for 2 degrees. Same behavior was recorded at Bedroom 1, the temperature was reduced 5 and 4 degrees at 9:00 and 10:00 am consecutively, and then the AirTube obtains reducing the temperature with range of 2.5 to 3 degrees for most of the day hours. On the other hand at Bedroom 2 the AirTube managed to decrease the temperature for only 1 degree from 8:00 am to 12:00 pm, then at 1:00 pm no difference was recorded in temperature, in the evening hours the performance improved to reach 3 degrees less than the temperature before installing the AirTube.

Table 2. Temperatures in the selected room before and after installing AirTubes.

\begin{tabular}{|c|c|c|c|c|c|c|c|c|}
\hline \multirow{3}{*}{ Time } & \multirow{2}{*}{\multicolumn{2}{|c|}{$\begin{array}{l}\begin{array}{l}\text { Master } \\
\text { Bedroom }\end{array} \\
\text { temperature } C^{\circ}\end{array}$}} & \multirow{2}{*}{\multicolumn{2}{|c|}{$\begin{array}{l}\text { Family Living } \\
\text { Area } \\
\text { temperature }\end{array}$}} & \multirow{2}{*}{\multicolumn{2}{|c|}{$\begin{array}{l}\text { Bedroom } 1 \\
\text { temperature }\end{array}$}} & \multirow{2}{*}{\multicolumn{2}{|c|}{$\begin{array}{l}\text { Bedroom } 2 \\
\text { temperature }\end{array}$}} \\
\hline & & & & & & & & \\
\hline & before & after & before & after & before & after & Before & after \\
\hline $\begin{array}{l}8: 00 \\
\text { AM }\end{array}$ & 33.2 & 29.5 & 32.5 & 30.5 & 32.9 & 29.4 & 31 & 30.1 \\
\hline $\begin{array}{l}9: 00 \\
\text { AM }\end{array}$ & 34.4 & 30.1 & 32.5 & 30.9 & 34.2 & 29.9 & 31.2 & 30.4 \\
\hline $\begin{array}{l}\text { 10:00 } \\
\text { AM }\end{array}$ & 34.1 & 30.8 & 33.1 & 31.3 & 34 & 30.8 & 31.8 & 31.1 \\
\hline $\begin{array}{l}\text { 11:00 } \\
\text { AM }\end{array}$ & 33.8 & 31.6 & 33.5 & 31.9 & 33.9 & 31.6 & 32.2 & 31.7 \\
\hline $\begin{array}{l}\text { 12:00 } \\
\text { PM }\end{array}$ & 34.3 & 32.3 & 34.5 & 32.6 & 34.6 & 32.3 & 33 & 32.9 \\
\hline 1:00 PM & 34.8 & 32.9 & 35.6 & 33.3 & 35.4 & 32.9 & 33.9 & 33.9 \\
\hline 2:00 PM & 35 & 33.1 & 36.9 & 33.3 & 35.7 & 33.1 & 34.6 & 33.9 \\
\hline 3:00 PM & 35.1 & 33.3 & 37.8 & 33.2 & 36 & 33.3 & 35.2 & 33.8 \\
\hline 4:00 PM & 35.3 & 33.5 & 38.8 & 33.3 & 36.3 & 33.4 & 35.7 & 33.8 \\
\hline 5:00 PM & 35.3 & 33.4 & 39.1 & 33.3 & 36.4 & 33.3 & 36 & 33.6 \\
\hline 6:00 PM & 34.8 & 32.6 & 38.6 & 32.8 & 35.8 & 32.4 & 35.6 & 32.9 \\
\hline 7:00 PM & 34.7 & 32.3 & 38.4 & 32.7 & 35.6 & 32.3 & 35.5 & 32.6 \\
\hline
\end{tabular}




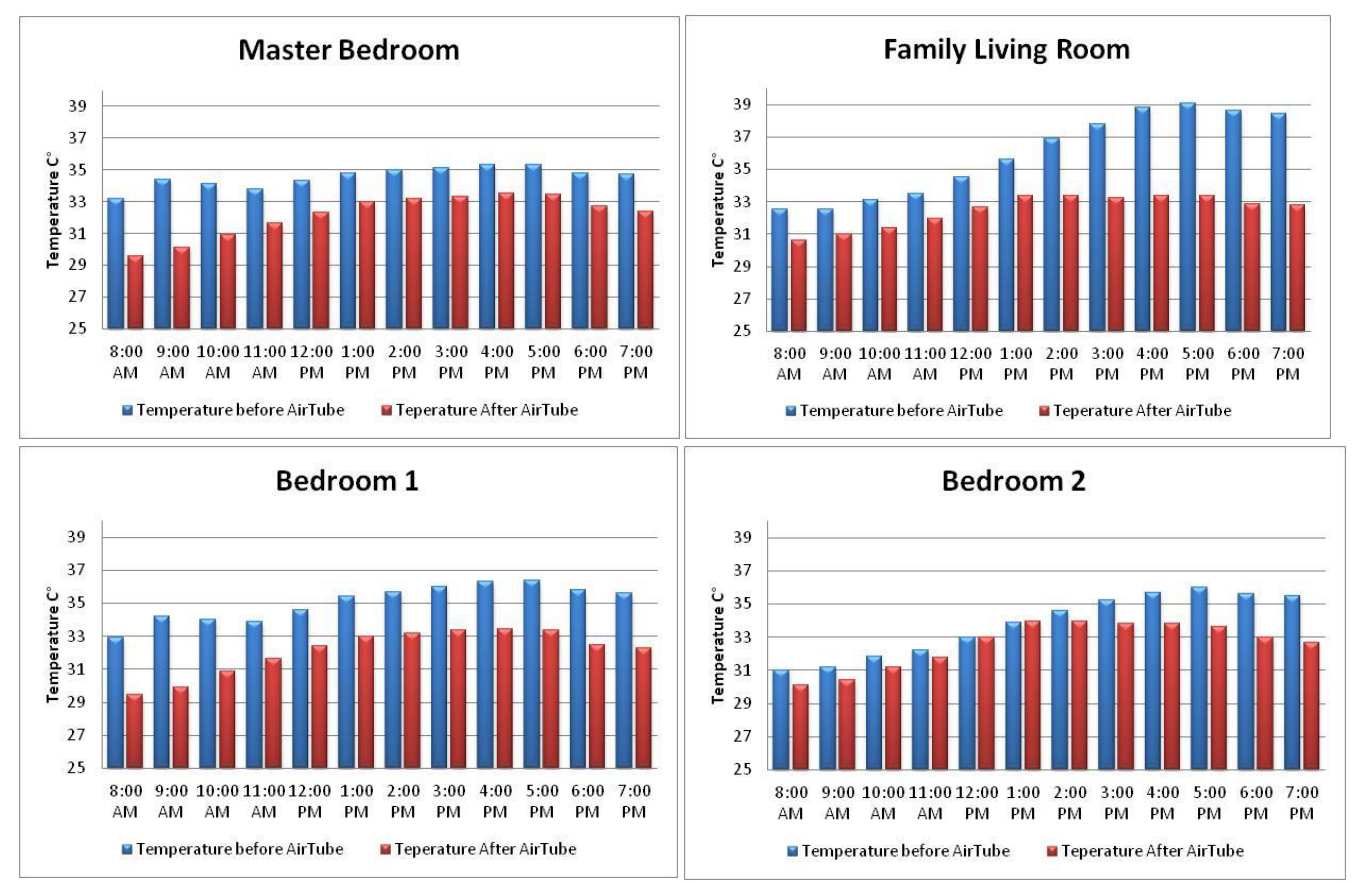

Figure 5, Chart lines of selected room's the temperature before and after adding the Air Tube.

\section{CONCLUSION}

The research finds that Air Tube device manages to adjust the atmosphere and decline air temperature inside the last storey's room in the semi-detached houses. Figure 5 shows that there are differences in the effect of Air Tube in the rooms based on the area, number of windows and orientation, and that will play a role in specifying the number and size of Air Tube which has to be installed in the room. This study concludes that the Air Tube is efficient to decrease the temperature of the semi-detached house's second storey for few degrees and it is a good sustainable solution for the exited houses in order to adjust the atmosphere to fit the thermal comfort standard in the tropical climate.

\section{REFERENCES}

BANSAL, N. K., RAJESH MATHUR, and M. S. BHANDARI*. "Solar Chimney for Enhanced Stack Ventilation ." Building and Environment, 1993: 373-377.

Bodart, M, and A De Herde. "Global energy savings in offices buildings by the use of daylighting." Energy and Buildings, 2002: Vol 34 (5) P 421-429.

El-Shorbagy, Abdel-moniem. "Design with Nature: Windcatcher as a Paradigm of Natural Ventilation Device in Buildings." International Journal of Civil \& Environmental Engineering IJCEE-IJENS, 2010.

El-Shorbagy, Abdel-moniem. "Traditional Islamic-Arab House: Vocabulary And Syntax." International Journal of Civil \& Environmental Engineering IJCEE-IJENS, 2010. 
Hirunlabh, J, W Kongduang, P Namprakai, and J Khedari. "Study of natural ventilation of houses by a metallic solar wall under tropical climate." Renewable Energy, 1999: Vol 18 (1) P 109-119.

Hirunlabh, J., and W., Namprakai, P., \& Khedari, J Kongduang. n.d.

Hirunlabh, J., W. Kongduang, P. Namprakai, and J. Khedari. "Study of natural ventilation of houses by a metallic solar wall under tropical climate." Renewable Energy, 1999: 109-119.

Ihm, Pyonchan, Abderrezek Nemri, and Moncef Krarti. "Estimation of lighting energy savings from daylighting." Building and Environment, 2009: Vol 44 (3) P 509-514.

$\mathrm{Ju}$, Seo Ryeung, and Saari Bin Omar. "A Typology of Modern Housing in Malaysia." International Journal of Human Ecology, 2010: Vol 11 (1) P 109-119.

Lipinga, Wang, and Wong Nyuk Hien. "Applying Natural Ventilation for Thermal Comfort in Residential Buildings in Singapore." Architectural Science Review, 2007: Vol 50 (3), P 224-233.

Montazeri, H., F. Montazeri, R. Azizian, and S. Mostafavi. "Two-sided wind catcher performance evaluation using experimental, numerical and analytical modeling." Renewable Energy, 2010: 1424-1435.

Organization, Worl Health. ndoor Environment: Health Aspects of Air Quality, Thermal Environment, Light and Noise. London : World Health Organisation, 1990.

Rahman, Abdul Malik Abdul. "Housing Design in relation to Environmental Comfort." Building Research \& Information, 1995: Vol 23 (1) P 49-54.

Singha, Manoj Kumar, Sadhan Mahapatrab, and S.K. Atreya. "Thermal performance study and evaluation of comfort temperatures in vernacular buildings of North-East India." Building and Environment, 2010: Vol 45 (2) P 320-329.

statistics, Department of. Population Distribution and Basic Demographic Characteristics . Kuala Lumpur : Banci Gensus, 2010.

The Canadian Index. Temperature/Humidity Comfort Level. October 10, 2009. http://www.gorgecreekorchards.com.au/conditionscolour.html.

Wikipedia. Sungai Petani. 2013. http://en.wikipedia.org/wiki/Sungai_Petani. 